\title{
Farklı Islah Yöntemlerinin Hıdırellez Kamçısı (Asphodelus aestivus Brot.)'nın Oranı ile Meranın Verimi ve Ot Kalitesine Etkileri
}

\author{
Firat Alatürk* Ahmet Gökkuş
}

\author{
Çanakkale Onsekiz Mart Üniversitesi Ziraat Fakültesi, Tarla Bitkileri Bölümü, 17020, Çanakkale, Türkiye \\ *Sorumlu yazar: alaturkf@comu.edu.tr
}

Geliş Tarihi: 04.02.2019

Kabul Tarihi: 04.04.2019

\section{$\ddot{\mathbf{O} z}$}

$\mathrm{Bu}$ araştırma Akdeniz iklim kuşağında yaygın bir şekilde bulunan, tohum ve yumruları ile çoğalan ve zehirli bileşikleri bünyesinde bulunduran hıdırellez kamçısı (Asphodelus aestivus Brot.) ile mücadelede farklı ıslah yöntemleri kullanılarak hem mera otunun verim ve kalitesinde hem de hıdırellez kamçısının oranındaki değişimleri belirlemek amacıyla yürütülmüştür. Deneme Çanakkale ili Biga ilçesi Gerlengeç köyünde 2014-2017 yıllarında yürütülmüştür. Araştırma bölünmüş parseller düzenlemesine göre üç tekerrürlü olarak kurulmuştur. Ana parsellere 5 1slah uygulaması (kontrol, sökme, biçme, herbisit ve gübre), alt parsellere ise tohumlama (tohumlanan ve tohumlanmayan) yerleştirilmiştir. Her alt parsel $50 \mathrm{~m}^{2}(10 \times 5 \mathrm{~m})$ alana sahip olmuştur. Sökme çizel ile 10-15 cm derinlikten, biçme ise tamburlu biçim makinesi ile 2-3 cm anız kalacak şekilde yapılmıştır. Herbisit olarak metsulfuron metil $60 \mathrm{WG}$ + tribenuron metil $75 \mathrm{WG}$ kullanılmıştır. Gübre olarak dekara $5 \mathrm{~kg} \mathrm{~N}$ ve $5 \mathrm{~kg} \mathrm{P}_{2} \mathrm{O}_{5}$ verilmiştir. Tohumlama amaciyla yonca (Medicago sativa), korunga (Onobrychis viciifolia), domuz ayrığı (Dactylis glomerata) ve çok yıllık çim (Lolium perenne) karışımı ekilmiştir. Denemede bitki örtüsü ve hıdırellez kamçısının gelişimi incelenmiştir. Islah uygulamalarına göre meranın kuru ot verimi ortalama $44 \mathrm{~kg} / \mathrm{da}$ artmıştır. En yüksek verim artışı herbisit ve gübre uygulanan parsellerde gerçekleşmiştir. Hıdırellez kamçısının oranı gübreleme dışındaki ıslah yöntemleriyle önemli oranda azalmıştır. Otun ham protein oranı sökme, biçme ve gübreleme, ham kül oranı ise biçme, herbisit, sökme ve gübreleme parsellerinde daha yüksek olmuştur. Hıdırellez kamçısının yoğun olduğu benzer meralarda hem bitki ile mücadele hem de meranın ot verimi ve kalitesi artırmak veya korumak amacıyla sökme ve/veya yırtma ile birlikte biçme yapılması önerilmiştir.

Anahtar Kelimeler: Asphodelus aestivus, Sökme, Biçme, Herbisit, Tohumlama, Ot Verimi

\section{The Effects of Different Improvement Methods on the Ratio of Asphodelus aestivus Brot. Yield and Quality of Hay in Rangelands \\ Abstract}

This research work has been carried out in order to determine the changes in the yield and quality of the rangelands as well as in the ratio of Summer asphodel (Asphodelus aestivus Brot.) with the application of different improvement methods in the control of $A$. aestivus, which is commonly found in the Mediterranean climatic zone and grown with its seeds and tubers by containing poisonous compounds. Experiments have been conducted in Gerlengeç Village of Biga District of Çanakkale Province between the years 2014-2017. Research experiments have been established according to the randomized complete block design using 3 replications. Five improvement practices (control, pulling, mowing, herbicide and fertilizer) have been placed in the main plots, while seeding (seeded and non-seeded) has been found in sub plots. Each sub plot had an area of $50 \mathrm{~m}^{2}(10 \times 5$ $\mathrm{m})$. Pulling was done in the depth of $10-15 \mathrm{~cm}$ by using a chisel, and the mowing was done with a tumbled shape machine by leaving 2-3 cm stubble on ground. Metsulfuron methyl $60 \mathrm{WG}$ and tribenuron methyl $75 \mathrm{WG}$ were used as herbicides. $5 \mathrm{~kg} \mathrm{~N}$ and $5 \mathrm{~kg} \mathrm{P}_{2} \mathrm{O}_{5} / \mathrm{da}$ were applied as fertilizer. Mixtures of alfalfa (Medicago sativa), sainfoin (Onobrychis viciifolia), cocksfoot (Dactylis glomerata) and perennial ryegrass (Lolium perenne) have been sown for the purpose of insemination. Vegetative cover and growth of summer asphodel were investigated in this research work. The average dry hay yield of rangelands has been increased up to $44 \mathrm{~kg} / \mathrm{da}$ according to different improvement practices. An increase in the highest yield has been occurred into the herbicide and fertilizer treated plots. The ratio of summer asphodel significantly decreased by improvement practices other than fertilizer. The crude protein ratio of the hay has been recorded higher in pulling, mowing and fertilizer; while the crude ash ratio in mowing, herbicide, pulling and fertilizer treated plots. It is recommended that both pulling and mowing practices should be applied along with cutting and/or mowing in order to increase or maintain the yield and quality of hay in summer asphodel dominated rangelands having similar climatic conditions.

Key words: Asphodelus aestivus, pulling, cutting, herbicide, seeding hay quality 


\section{Giriş}

Ülkemizde hayvancılık (özellikle küçükbaş) meraya dayalı yapılmasına karşın, genelde meralarımızın \%87,6'sı zayıf ve orta durumda olup, ot verimi ve kalitesini önemli ölçüde kaybetmiştir (Avağ ve ark. 2012). Yönetim ilkelerinin uygulanmamasının doğurduğu bu durum sonucunda meradaki arzulanan türlerin yerini otlanmayan istilacı, zararlı ve zehirli bitkilerin almıştır (Tükel ve Hatipoğlu, 2001). Bu türler içerisinde önemli bir yere sahip olan hıdırellez kamçısı (çirişotu), zambakgiller (Liliaceae) familyasına ait çok yıllık yumrulu bir bitki olup, Akdeniz ikliminin hâkim olduğu Ege, Marmara, Akdeniz ve Güneydoğu Anadolu Bölgelerinde yayılmıştır. Asphodelus cinsine mensup türler özellikle Ege ve Doğu Akdeniz meralarında \%10-50 gibi büyük oranlara kadar ulaşmaktadır (Bilgir, 1961; Önder ve Karsavuran, 1986; Uygun ve ark. 1994). Hatta Ege Bölgesi meralarında Asphodelus oranının 10 adet $/ \mathrm{m}^{2}$ ye kadar vardığı belirtilmiştir (Eltez, 1995). Dünyada da çoğunlukla Akdeniz ülkelerinde yaygın olmakla birlikte (Polunin ve Huxley, 1987; Diaz Lifante, 1996), genel olarak İtalya ve Yunanistan'dan Fransa'ya kadar dağılmıştır (EUNİS, 2010). Deniz seviyesinden 1000 m yüksekliğe kadar yetişebilmektedir. Genellikle meraların kireçli toprakları ile yol kenarları ve terkedilmiş alanlarda yoğunlaşmış istilacı bir bitkidir. Bitki hem generatif (tohum) hem de vejetatif (yumru) olarak çoğalmakla birlikte, genelde yumruları ile çoğalırlar. Hermafrodit çiçekleri polen ve balözü bakımından zengindir (Weryszko-chemielewska ve ark. 2006). Meyveleri haziran ayında oluşur (Sawidis ve ark. 2005). Tohumları manto ve müsilaj maddeleri ile kaplı olduğu için düşük sıcaklıklarda bile çimlenebilir. Tohumların çimlenebilmesi için mutlak ışığa ihtiyaç duyar ve en iyi çimlenme toprak tabakasının $1 \mathrm{~cm}$ altında gerçekleşir. Hıdırellez kamçısının boyu 50-170 cm olup, $12 \mathrm{~cm}$ uzunluğunda ve $4 \mathrm{~cm}$ çapında yumrulara sahiptir. Bitkinin etli yaprakları hayvanların otlanmasını engelleyen steroit saponin gibi glikozit yapıdaki maddeleri içermektedirler. Yaprakların kurumasıyla azalan glikozit oranına bağlı olarak otlanmaktadır (Dahlgren ve ark. 1985). Ayrıca bitkinin çeşitli organlarında otlayan hayvanlar için savunma mekanizmaları içerisinde olan kalsiyum oksalat ve rafid kristalleri bulunmaktadır (Weryszko-chemielewska ve ark. 2006). Bitkinin yaprakları haziran ayında meyvelerin olgunlaşmasından önce kurumaya başlar.Hıdırellez kamçısı yeşil halde otlayan hayvanlar için zehirli olduğundan ve Akdeniz kuşağı meralarında oldukça yaygın olarak bulunduğundan, bu çalışmada bitkinin vejetasyondan uzaklaştırılarak veya oranı azaltılarak meranın ve hayvansal ürünlerin verim ve kalitelerini artırmak amaçlanmıştır.

\section{Materyal ve Yöntem}

Araştırma Çanakkale İli Biga İlçesi Gerlengeç Köyünde 2014-2017 yıllarında yürütülmüştür. Çanakkale'de uzun yıllar yıllık ortalama sıcaklık $15,8^{\circ} \mathrm{C}$ olurken, deneme yıllarında $16,1,16,5$ ve $16,1^{\circ} \mathrm{C}$ olarak ölçülmüştür. Araştırmanın yürütüldüğg̈ dönemde özellikle çalışmanın ikinci yılında ortalama sıcaklık değerleri uzun yılların üzerine çıkmıştır. En yüksek sıcaklıklar temmuz ve ağustos aylarında görülürken, en düşük sıcaklıklar ocak ve şubat aylarında kaydedilmiştir. Araştırma yıllarına ait yıllık toplam yağış miktarları 650,3, 581,9 ve 656,5 mm iken, uzun yıllar ortalamas 1711,2 mm'dir. Denemenin yürütüldüğ̈ süreçte yıllık yağış miktarı azalmıştır. Özellikle çalışmanın ikinci yılında düşen yağış miktarı uzun yıllar ortalamasının 130 mm altında kalmıştır (Çizelge 1).

Çizelge 1. Çanakkale ilinin uzun yıllar ve araştırma dönemine ait ortalama iklim değerleri

\begin{tabular}{lrrrrrrrr}
\hline \multirow{2}{*}{ Aylar } & \multicolumn{3}{c}{ Aylı Ortalama Sicaklı $\left({ }^{\circ} \mathrm{C}\right)$} & \multicolumn{5}{c}{ Aylı Toplam Yağ 1 Ş $(\mathrm{mm})$} \\
\cline { 2 - 9 } & $1975-2014$ & 2015 & 2016 & 2017 & $1975-2014$ & 2015 & \multicolumn{1}{c}{2016} & 2017 \\
\hline Ocak & 7,0 & 6,7 & 7,0 & 3,9 & 81,7 & 116,8 & 110,2 & 155,6 \\
Şubat & 7,1 & 7,5 & 10,9 & 7,9 & 84,8 & 83,0 & 88,4 & 56,8 \\
Mart & 9,2 & 9,3 & 11,1 & 10,6 & 64,9 & 63,8 & 53,6 & 22,1 \\
Nisan & 13,0 & 11,9 & 15,7 & 13,3 & 60,7 & 78,2 & 15,0 & 14,9 \\
Mayis & 18,3 & 19,4 & 18,2 & 18,7 & 28,2 & 15,6 & 26,8 & 19,3 \\
Haziran & 23,0 & 22,0 & 24,5 & 23,9 & 35,2 & 65,0 & 39,9 & 36,8 \\
Temmuz & 26,3 & 26,2 & 26,9 & 26,6 & 8,1 & 0,0 & 0,0 & 17,2 \\
Ağustos & 26,3 & 27,1 & 27,0 & 26,7 & 13,3 & 3,2 & 0,0 & 0,0 \\
Eylül & 21,7 & 23,4 & 22,5 & 22,2 & 67,7 & 64,6 & 1,8 & 11,7 \\
Ekim & 16,3 & 17,0 & 17,1 & 15,7 & 73,1 & 110,5 & 8,6 & 58,3 \\
Kasım & 12,7 & 14,4 & 12,5 & 12,5 & 64,4 & 48,0 & 209,0 & 117,3 \\
Aralı & 9,0 & 8,2 & 5,0 & 11,1 & 129,0 & 1,6 & 28,6 & 146,5 \\
\hline Ortalama & 15,8 & 16,1 & 16,5 & 16,1 & & & & \\
Toplam & & & & & 711,2 & 650,3 & 581,9 & 656,5 \\
\hline
\end{tabular}


Araştırma alanının toprakları genel olarak killi yapıdadır. Organik madde içeriği ortalama \%2,41 ile orta sinıftadır. Topraklar nötr $(\mathrm{pH}: 7,08)$, tuzsuz $(1,00 \mathrm{mS} / \mathrm{cm})$ ve kireçlidir $(\% 2,74$ $\left.\mathrm{CaCO}_{3}\right)$. Toprakların fosforu az $(2,51 \mathrm{~kg} / \mathrm{da})$, potasyumu $(43,61 \mathrm{~kg} / \mathrm{da})$ yeterli, kalsiyum $(7868 \mathrm{ppm})$ ve magnezyum içeriği $(669,6 \mathrm{ppm})$ fazla, bakır düzeyi yeterli (1,83 ppm), çinko az (0,24 ppm), demir $(15,50 \mathrm{ppm})$ ve mangan $(23,73 \mathrm{ppm})$ yeterlidir.

Araştırma şansa bağlı tam bloklar deneme deseninde bölünmüş parseller düzenlemesine göre üç tekerrürlü olarak kurulmuştur. Ana parsellere 5 1slah uygulaması (kontrol, sökme, biçme, herbisit ve gübre) ve alt parsellere tohumlama (tohumlanan ve tohumlanmayan) yerleştirilmiştir. Her alt parsel $50 \mathrm{~m}^{2}(10 \times 5 \mathrm{~m})$ alana sahiptir. Sökme çizel ile $10-15 \mathrm{~cm}$ derinlikten, biçme ise tamburlu biçim makinesi ile 2-3 cm anız kalacak şekilde yapılmıştır. Herbisit olarak metsulfuron metil $60 \mathrm{WG}+$ tribenuron metil $75 \mathrm{WG}$ etken maddelerine sahip ot ilacından dekara $1 \mathrm{~g}$ olacak şekilde uygulanmıştır. Gübre olarak dekara $5 \mathrm{~kg} \mathrm{~N}$ ve $5 \mathrm{~kg} \mathrm{P}_{2} \mathrm{O}_{5}$ olacak şekilde kompoze gübre (20-20-0) verilmiştir. $\mathrm{Bu}$ uygulamaların 7 Kasım 2014 tarihinde gerçekleştirilmiştir. Tohumlamada yonca (Medicago sativa) (GA), korunga (Onobrychis viciifolia) (yerel popülasyon), domuz ayrı̆̆ı (Dactylis glomerata) (Lidaglo) ve çok yıllık çim (Lolium perenne) (Temproano) kullanılmıştır. Denemede bitki örtüsü ve hıdırellez kamçısının gelişimi incelenmiştir. Ot verimleri Altın ve Gökkuş (1998), ham protein ve ham kül içerikleri AOAC (1990)'a göre belirlenmiştir. Tür bileşimi ağırlık esasına göre tespit edilmiştir (Gökkuş ve ark. 1995). Araştırmadan elde edilen veriler bölünmüş (aylık örnekleme yapılmayan) ve bölünen bölünmüş (aylık örnekleme yapılan) parseller deneme desenine uygun olarak SAS istatistik paket programında (SAS V9.0) istatistiki analize tabi tutulmuştur. Ortalamalar arasındaki farklılıklar AÖF çoklu karşılaştırma testi ile değerlendirilmiştir.

\section{Bulgular ve Tartışma \\ Kuru Ot Verimi}

Yılların ortalamasına göre, en yüksek kuru ot verimi $(408,3 \mathrm{~kg} / \mathrm{da})$ gübreleme parsellerinde saptanırken, bunu biçilen ve herbisit püskürtülen parsellerin verimleri izlemiştir. Kontrol ve sökme parselleri en az verimlere sahip olmuştur. Kuru ot verimi denemenin ilk yılından son yılına kadar sürekli ve önemli artış göstermiştir. Tohumlama meranın kuru ot üretimini önemli oranda artırmıştır (Çizelge 2).

Çizelge 2. Farklı 1slah uygulamalarına ve yıllara göre ortalama kuru ot verimleri $(\mathrm{kg} / \mathrm{da})$

\begin{tabular}{|c|c|c|c|c|}
\hline Uygulama & 2015 & 2016 & 2017 & Ortalama \\
\hline Kontrol & 289,2 & 348,1 & 364,2 & $333,8 \mathrm{D}$ \\
\hline Sökme & 303,8 & 373,8 & 398,5 & $358,7 \mathrm{C}$ \\
\hline Biçme & 307,1 & 404,4 & 404,5 & $372,0 \mathrm{~B}$ \\
\hline Herbisit & 296,9 & 399,2 & 415,1 & $370,4 \mathrm{~B}$ \\
\hline Gübreleme & 335,7 & 438,1 & 451,2 & $408,3 \mathrm{~A}$ \\
\hline Ortalama & $306,5 \mathrm{C}$ & $392,7 \mathrm{~B}$ & $406,7 \mathrm{~A}$ & \\
\hline \multicolumn{5}{|c|}{ Tohumlama } \\
\hline Tohumlanmayan & 298,5 & 370,7 & 389,0 & $352,7 \mathrm{~B}$ \\
\hline Tohumlanan & 314,5 & 414,7 & 424,4 & $384,6 \mathrm{~A}$ \\
\hline Önemlilik & \multicolumn{4}{|c|}{$\mathrm{P}_{\mathrm{U}}: 0,0001, \mathrm{P}_{\mathrm{Y}}: 0,0001, \mathrm{P}_{\mathrm{T}}: 0,0001, \mathrm{P}_{\mathrm{U}^{*} \mathrm{Y}}: 0,4564$} \\
\hline
\end{tabular}

Meranın kuru ot veriminde en büyük artış gübreleme ile sağlanmıştır. Gübre olarak verilen N ve P bitkideki fizyolojik olaylar üzerinde en etkili olanlardır ve bitkiler tarafından diğer elementlere göre daha çok alınırlar. Buna karşın özellikle $\mathrm{N}$ toprakta çok hareketli olduğundan, alınma, yıkanma ve buharlaşma ile kolaylıkla uzaklaşmaktadır (Whitehead, 2000). Bunun yanında yapraktaki azot miktarı ile fotosentez kapasitesi arasında yakın ilişkinin bulunması (Gulmon ve Chu, 1981; Evans, 1989), kuru madde üretiminde bu elementin önemini göstermektedir. Diğer taraftan toprakta fosfor miktarı da yetersiz seviyededir. Dolayısıyla gübreleme ile alınabilir N ve P miktarının artırılması doğal olarak ot verimini de artırmıştır. Bu sebeple yüksek dozlarda olmamak kaydıyla yapılan çalışmaların birçoğunda gübreleme sonucunda ot veriminin arttığı rapor edilmiştir (Alatürk, 2012).

Sökme uygulaması yırtılarak havalanan toprakların mineralizasyon kapasitesini yükseltmiş ve buna bağlı olarak besin elementi elverişliliğini artırmıştır. Dolayısıyla sökmeye bağlı olarak sıkışmış 
topraklarda yerleşik türlerden gelişim göstermeyen bitkilerin büyüme ve gelişmeleri teşvik edilmiş ve bu sebeple ot verimi artmıştır (Ahuja, 1972; Rimmer, 1979; Gökkuş, 1984).

Biçme ile fotosentez dokuları zarar gören hıdırellez kamçısı, büyüme ve gelişmede özümleme ürünleri yerine yumrularında depoladığı yedek besin maddelerini kullanmış ve yılların ilerlemesine bağlı olarak yumruda yeterli miktarda besin maddesi depolayamadığı için vejetatif gelişimi zayıflamıştır. Bundan dolayı biçilen parsellerde hıdırellez kamçısının gelişimi engellenerek botanik kompozisyondaki oranı azalmıştır. Diğer taraftan biçme sonucu botanik kompozisyonda önemli oranlarda yer tutan hıdırellez kamçısının büyüme ve gelişmesi yavaşladığı için bitki örtüsündeki diğer türlerle olan rekabet gücünü kaybetmiştir. Rekabet üstünlüğüne sahip diğer türler de biçme ile kurumuş bitki artıklarının temizlenmesi ve biçimden sonra genç sürgünlerin gelişmesi ile çok daha fazla kütle üretmiştir. Buna bağlı olarak da meranın ot üretimlerinde önemli artış kaydedilmiştir.

Herbisit uygulaması ile yabancı otların gelişimi engellenirken, arzu edilen türlerin büyüme ve gelişmesi teşvik edilmektedir (Stafford ve ark. 1980). Dolayısıyla uygulanan yabancı ot ilacı hıdırellez kamçısının gelişimini baskı altına alırken, diğer bitkiler buna karşı rekabet üstünlüğü sağlayarak daha fazla büyüme ve gelişme şansı yakalamıştır. Sonuçta Mullen ve ark. (1974) ve Gökkuş ve Koç (1995)'un da belirttiği gibi meranın ot verimi artmıştır.

Genelde başarılı bir tohumlamada kullanılan türler verimli olduklarından, bitki örtüsüne dahil olmaları ile birlikte meranın toplam kuru madde üretimini artırmaktadır. Fakat bu çalışmada ekilen türlerin meranın ot verimine önemli katısının olduğu söylenemez. Dolayısıyla üretim artışında, tohumlamadan çok, öncesindeki tohum yatağı açmak amaciyla toprağın yırtılmasına bağlı olarak sıkışan toprağın havalanması etkili olmuştur. Zira sıkışan topraklarda su geçişi, havalanma, kök büyümesi ve mikroorganizma faaliyetleri en az seviyededir (Heady ve Child, 1994). Mikroorganizma faaliyetinin artışına bağlı olarak da organik maddenin parçalanması hızlanmakta ve topraktaki besin elementlerinin elverişliliği artmaktadır (Weight ve White, 1974). Nitekim toprağın yırtılmasına bağlı olarak meranın ot verimlerinde artışların sağlandığına dair birçok çalışma mevcuttur (Gökkuş, 1984; Griffith ve ark. 1985).

\section{Tür Bileşimi}

Buğdaygiller: Uygulamalara göre en yüksek buğdaygil oranı $(\% 36,52)$ hıdırellez kamçısının söküldügü parsellerde belirlenirken, bunu herbisit atılan ve kontrol parsellerinin buğdaygil oranları izlemiştir. En az buğdaygil biçilen ve gübrelenen parsellerde tespit edilmiştir. Yıllara bağlı olarak meranın buğdaygil oranı önce azalmış, sonra artmıştır. Tohumlama ile de bitki örtüsünün buğdaygil oranında artışlar olmuştur (Çizelge 3).

Çizelge 3. Farklı 1slah uygulamalarına ve yıllara göre ortalama buğdaygil oranları (\%)

\begin{tabular}{|c|c|c|c|c|}
\hline Uygulama & 2015 & 2016 & 2017 & Ortalama \\
\hline Kontrol & $33,27 \mathrm{e}$ & $27,96 \mathrm{~m}$ & $29,52 \mathrm{j}$ & $30,25 \mathrm{C}$ \\
\hline Sökme & $35,70 \mathrm{~b}$ & $33,22 \mathrm{f}$ & $40,66 \mathrm{a}$ & $36,52 \mathrm{~A}$ \\
\hline Biçme & 26,48 o & $27,71 \mathrm{n}$ & $29,12 \mathrm{k}$ & $27,77 \mathrm{E}$ \\
\hline Herbisit & $34,22 \mathrm{c}$ & $34,05 \mathrm{~d}$ & $30,62 \mathrm{~h}$ & $32,96 \mathrm{~B}$ \\
\hline Gübreleme & 29,991 & 28,441 & $30,87 \mathrm{~g}$ & $29,77 \mathrm{D}$ \\
\hline Ortalama & $31,93 \mathrm{~B}$ & $30,28 \mathrm{C}$ & $32,16 \mathrm{~A}$ & \\
\hline \multicolumn{5}{|c|}{ Tohumlama } \\
\hline Tohumlanmayan & $26,59 \mathrm{f}$ & $26,91 \mathrm{e}$ & $31,31 \mathrm{~d}$ & $28,27 \mathrm{~B}$ \\
\hline Tohumlanan & $37,27 \mathrm{a}$ & $33,65 \mathrm{~b}$ & $33,00 \mathrm{c}$ & $34,64 \mathrm{~A}$ \\
\hline Önemlilik & \multicolumn{4}{|c|}{$\mathrm{P}_{\mathrm{U}}: 0,0001, \mathrm{P}_{\mathrm{Y}}: 0,0001, \mathrm{P}_{\mathrm{T}}: 0,0001, \mathrm{P}_{\mathrm{U}^{*} \mathrm{Y}}: 0,4564$} \\
\hline
\end{tabular}

Baklagiller: Üç yıllık ortalamada uygulamalara göre en yüksek baklagil oranı biçme yapılan parsellerde belirlenirken, herbisit ve sökme parsellerinin baklagil oranları ikinci grupta yer almıştır. Kontrol parselinde en az baklagil türüne rastlanmıştır. Meradaki baklagil oranı çalışmanın ilk yılından son yılına kadar sürekli artmıştır. Tohumlama ile de baklagil oranında artış görülmüş̧ür (Çizelge 4). 
Çizelge 4. Farklı 1slah uygulamalarına ve yıllara göre ortalama baklagil oranları (\%)

\begin{tabular}{|c|c|c|c|c|}
\hline Uygulama & 2015 & 2016 & 2017 & Ortalama \\
\hline Kontrol & 3,211 & 6,291 & $7,17 \mathrm{~h}$ & $5,55 \mathrm{D}$ \\
\hline Sökme & $5,70 \mathrm{j}$ & $8,50 \mathrm{f}$ & $10,36 \mathrm{c}$ & $8,19 \mathrm{~B}$ \\
\hline Biçme & $7,68 \mathrm{~g}$ & $9,82 \mathrm{~d}$ & $11,52 \mathrm{~b}$ & $9,67 \mathrm{~A}$ \\
\hline Herbisit & $3,53 \mathrm{kl}$ & $8,34 \mathrm{f}$ & $12,81 \mathrm{a}$ & $8,23 \mathrm{~B}$ \\
\hline Gübreleme & $3,76 \mathrm{k}$ & $7,31 \mathrm{~h}$ & $9,06 \mathrm{e}$ & $6,71 \mathrm{C}$ \\
\hline Ortalama & $4,78 \mathrm{C}$ & $8,05 \mathrm{~B}$ & $10,19 \mathrm{~A}$ & \\
\hline \multicolumn{5}{|c|}{ Tohumlama } \\
\hline Tohumlanmayan & $2,77 \mathrm{f}$ & $5,18 \mathrm{e}$ & $7,37 \mathrm{c}$ & $5,11 \mathrm{~B}$ \\
\hline Tohumlanan & $6,78 \mathrm{~d}$ & $10,92 \mathrm{~b}$ & $13,00 \mathrm{a}$ & $10,23 \mathrm{~A}$ \\
\hline Önemlilik & \multicolumn{4}{|c|}{$\mathrm{P}_{\mathrm{U}}: 0,0001, \mathrm{P}_{\mathrm{Y}}: 0,0001, \mathrm{P}_{\mathrm{T}}: 0,0001, \mathrm{P}_{\mathrm{U}^{*} \mathrm{Y}}: 0,0001$} \\
\hline
\end{tabular}

Diğer familyalar: Islah uygulanmayan kontrol parseli en yüksek diğer familyalardan türe $(\% 64,20)$ sahip olmuştur. Sökme ve herbisit parsellerinde ise diğer familyalar en az tür oranı ile temsil edilmiştir. Vejetasyondaki diğer familyalardan türlerin oranları denemenin başlangıcından itibaren yıllara bağlı olarak sürekli azalmıştır. Aynı şekilde tohumlama ile de diğer türlerin oranlarında önemli azalma olmuştur (Çizelge 5).

Çizelge 5. Farklı ıslah uygulamalarına ve yıllara göre ortalama diğer türlerin oranları (\%)

\begin{tabular}{|c|c|c|c|c|}
\hline Uygulama & 2015 & 2016 & 2017 & Ortalama \\
\hline Kontrol & $63,53 \mathrm{~d}$ & $65,76 \mathrm{~b}$ & $63,31 \mathrm{~d}$ & $64,20 \mathrm{~A}$ \\
\hline Sökme & $58,60 \mathrm{~h}$ & $58,29 \mathrm{~h}$ & $48,97 \mathrm{k}$ & $55,29 \mathrm{E}$ \\
\hline Biçme & $65,84 \mathrm{~b}$ & $62,47 \mathrm{e}$ & $59,36 \mathrm{~g}$ & $62,56 \mathrm{C}$ \\
\hline Herbisit & $62,25 \mathrm{e}$ & 57,611 & $56,57 \mathrm{j}$ & $58,81 \mathrm{D}$ \\
\hline Gübreleme & $66,25 \mathrm{a}$ & $64,25 \mathrm{c}$ & $60,08 \mathrm{f}$ & $63,52 \mathrm{~B}$ \\
\hline Ortalama & $63,29 \mathrm{~A}$ & $61,67 \mathrm{~B}$ & $57,66 \mathrm{C}$ & \\
\hline \multicolumn{5}{|c|}{ Tohumlama } \\
\hline Tohumlanmayan & $70,64 \mathrm{a}$ & $67,91 \mathrm{~b}$ & $61,31 \mathrm{c}$ & $66,62 \mathrm{~A}$ \\
\hline Tohumlanan & $55,95 \mathrm{~d}$ & $55,44 \mathrm{e}$ & $54,00 \mathrm{f}$ & $55,13 \mathrm{~B}$ \\
\hline Önemlilik & \multicolumn{4}{|c|}{$\mathrm{P}_{\mathrm{U}}: 0,0001, \mathrm{P}_{\mathrm{Y}}: 0,0001, \mathrm{P}_{\mathrm{T}}: 0,0001, \mathrm{P}_{\mathrm{U}^{*} \mathrm{Y}}: 0,0001$} \\
\hline
\end{tabular}

Hıdırellez kamçısı: Üç yıllık ortalamada hıdırellez kamçısı sökme ve biçme parsellerinde en düşük orana sahip olurken, gübreleme parselinde kontrol parselinin de üzerinde bir oran ile en yüksek seviyeye ulaşmıştır. Yıllar içindeki değişimi de azalan bir eğilim içerisinde olmuştur. Tohumlama yapılan parsellerde hıdırellez kamçısının oranı yarıya inmiştir (Çizelge 6).

Çizelge 6. Farklı ıslah uygulamalarına ve yıllara göre ortalama hıdırellez kamçısı oranları (\%)

\begin{tabular}{|c|c|c|c|c|}
\hline Uygulama & 2015 & 2016 & 2017 & Ortalama \\
\hline Kontrol & $34,98 \mathrm{~g}$ & $39,22 \mathrm{~d}$ & $39,22 \mathrm{e}$ & $37,80 \mathrm{~B}$ \\
\hline Sökme & 25,281 & 24,301 & $24,84 \mathrm{k}$ & $24,81 \mathrm{E}$ \\
\hline Biçme & $32,94 \mathrm{~h}$ & $23,46 \mathrm{~m}$ & 19,61 o & $25,34 \mathrm{D}$ \\
\hline Herbisit & $29,59 \mathrm{c}$ & $24,93 \mathrm{j}$ & $20,15 \mathrm{n}$ & $28,22 \mathrm{C}$ \\
\hline Gübreleme & $43,24 \mathrm{a}$ & $41,44 \mathrm{~b}$ & $36,33 \mathrm{f}$ & $40,35 \mathrm{~A}$ \\
\hline Ortalama & $35,21 \mathrm{~A}$ & $30,67 \mathrm{~B}$ & $28,03 \mathrm{C}$ & \\
\hline \multicolumn{5}{|c|}{ Tohumlama } \\
\hline Tohumlanmayan & $45,67 \mathrm{a}$ & $41.43 \mathrm{~b}$ & $39.30 \mathrm{c}$ & $42.13 \mathrm{~A}$ \\
\hline Tohumlanan & $24,76 \mathrm{~d}$ & $19.91 \mathrm{e}$ & $16.75 \mathrm{f}$ & $20.47 \mathrm{~B}$ \\
\hline Önemlilik & \multicolumn{4}{|c|}{$\mathrm{P}_{\mathrm{U}}: 0,0001, \mathrm{P}_{\mathrm{Y}}: 0,0001, \mathrm{P}_{\mathrm{T}}: 0,0001, \mathrm{P}_{\mathrm{U}^{*} \mathrm{Y}}: 0,0001$} \\
\hline
\end{tabular}

Araştırmada meraların önemli yabancı otu olan hıdırellez kamçısı ile mücadele amaçlandığı için, yapılan uygulamalar bu bitkiyi vejetasyondan uzaklaştırmaya yönelik olmuştur. Sökme, biçme ve herbisit uygulamalarında bu belirli ölçüde başarılmıştır. Bitki örtüsünün yaklaşık 1/3'ünü kaplayan hıdırellez kamçısının oranının azaltılması, diğer türlerin gelişimi için daha uygun ortam hazırlamıştır. Bunun sonucunda baklagil ve buğdaygillerin oranı yükselmiştir.

Gübreleme ile hıdırellez kamçısı dışındaki türlerin gelişmesi teşvik edilerek, bu türlere rekabet üstünlüğü sağlamak hedeflenmiştir. Fakat bu hedefe ulaşılamayıp, hıdırellez kamçısı gübreden de 
yararlanarak bitki örtüsündeki varlığını korumuştur. Bu durum özellikle baklagil ve buğdaygillerde gübrelemeye bağlı bir artışa yol açmadığı gibi azaltmıştır. Ayrıca diğer familyalardan türlerin gübreye daha iyi tepki vermesi de bu azalmada etkili olmuştur. Tohumlamaya bağlı olarak baklagil ve buğdaygillerin oranlarında artışlar, ekilen yem bitkisi karışımlarının baklagil ve buğdaygillerden meydana gelmesi ve tohum yatağı hazırlığında toprağın bir miktar yırtılması ile hıdırellez kamçılarının zarar görmesinden ileri gelmiştir. Zira toprağın yırtılması (havalandırılması) özellikle tek yıllık bitkilerin gelişimini teşvik etmektedir (Gökkuş, 1984). Juncus effusus ile mücadele amaciyla yürütülen çalışmada (Sürmen, 2010) da freze uygulamasına bağlı olarak toprak havalanmış ve bunun sonucunda bitki örtüsünde baklagiller artmıştır.

\section{Ham Protein Oranı}

Yılların birleştirilmiş analizine göre, en yüksek ham protein içeriğine sahip otlar gübreleme $(\% 14,69)$ ve biçme $(\% 14,15)$ parsellerinden elde edilmiştir. En az ham protein içeren otlar ise kontrol parselinden hasat edilmiştir. Otun ham protein içeriği yıllara bağlı olarak sürekli artış göstermiştir. Ayrıca tohumlama ile de ham protein oranı yükselmiştir (Çizelge 7).

Çizelge 7. Farklı 1slah uygulamalarına ve yıllara göre otun ortalama ham protein oranları (\%)

\begin{tabular}{llccc}
\hline Uygulama & 2015 & 2016 & 2017 & Ortalama \\
\hline Kontrol & 10,02 & 11,12 & 11,72 & $10,95 \mathrm{C}$ \\
Sökme & 11,27 & 12,10 & 12,94 & $12,10 \mathrm{~B}$ \\
Biçme & 13,18 & 14,22 & 15,07 & $14,15 \mathrm{~A}$ \\
Herbisit & 10,05 & 11,05 & 11,37 & $10,82 \mathrm{C}$ \\
Gübreleme & 13,60 & 14,79 & 15,67 & $14,69 \mathrm{~A}$ \\
\hline Ortalama & $11,62 \mathrm{C}$ & $12,66 \mathrm{~B}$ & $13,35 \mathrm{~A}$ \\
\hline \multicolumn{5}{|}{} \\
\hline Tohumlanmayan & 11,31 & Tohumlama & $12,19 \mathrm{~B}$ \\
Tohumlanan & 11,93 & 12,29 & 12,96 \\
\hline Önemlilik & $\mathrm{P}_{\mathrm{U}}: 0,0001, \mathrm{P}_{\mathrm{Y}}: 0,0001, \mathrm{P}_{\mathrm{T}}: 0,0131, \mathrm{P}_{\mathrm{U}^{*} \mathrm{Y}}: 0,9952$ & 13,74 \\
\hline
\end{tabular}

Herbisit dışındaki ıslah uygulamaları mera otunun ham protein içeriğini artırmıştır. Gübreleme ile verilen azot, bitkilerin daha fazla azot alımına yardımcı olmaktadır. Alınan azot da metabolizma sonucunda proteinlerin yapısına katılıp ham protein içeriğini yükseltmektedir (Goetz, 1975; Serin, 1982; Mengel, 1984). Bu yüzden meralarda yapılan gübreleme çalışmalarında benzer sonuçlara ulaşılmıştır (Balabanlı ve ark. 2010; Alatürk, 2012).

Meranın biçilmesi sonucunda toprak yüzeyindeki önceki yıllardan kalan ve protein oranı düşük ölü otsu tabaka uzaklaştırılmakta (Koç ve ark. 2000; Andrae, 2003) ve mevcut bitkiler protein oranı yüksek yeni sap ve sürgün oluşturmaktadır (Koç ve ark. 2000). Hıdırellez kamçılarının söküldügü parsellerde de diğer türler kısmen tahrip olup yeniden büyüme sürecine girdikleri için, yeni büyüyen bitkilerdeki genç sürgünlerden dolayı ottaki ham protein oranı yükselmiş olabilir.

Ekim ile beraber bitki örtüsüne dahil edilen kaliteli yem bitkileri, tohumlanan parsellerin otunun daha yüksek ham protein içermesi beklenen bir sonuç olurdu. Fakat ekilen türlerin bitki örtüsünde tutunması genelde zayıf olduğu için, bu türlerin protein oranı üzerine etkisinin düşük

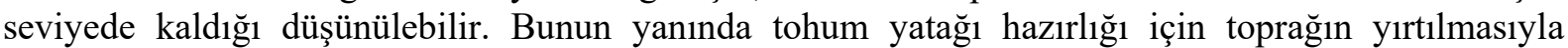
gevşeyen toprakta bitkilerin daha fazla gelişerek yeni sürgünler meydana getirmesi, otun ham protein oranının yükselmesinin temel sebebidir. Diğer taratan tohumlanan alanlarda diğer türlerin oranları azalıp baklagil ve buğdaygiller artış göstermiştir. Genel itibariyle protein içerikleri bakımından baklagillerin buğdaygillere (Traxler ve ark. 1998; Bakoğlu ve ark. 1999; Undersander ve ark. 2005), her ikisinin ise diğer familyalara oranla daha üstün olduğu bilinmektedir.

\section{Ham Kül Oranı}

Hıdırellez kamçısının biçildiği ve herbisit atıldığı parsellerin otu diğer uygulamalardan daha yüksek ham kül oranına sahip olmuştur. En düşük ham kül içeriği ise kontrol parsellerinin otunda tespit edilmiştir. Bunun yanında otun ham kül içeriği yıllara bağlı olarak önemli artış göstermiş̧tir. Ancak bu artı̧s ikinci yıldan sonra önemsiz olmuştur. Tohumlama sonucunda da ot örneklerinin ham kül içeriği yükselmiştir (Çizelge 8). 
Çizelge 8. Farklı sslah uygulamalarına ve yıllara göre ortalama ham kül oranları (\%)

\begin{tabular}{|c|c|c|c|c|}
\hline Uygulama & 2015 & 2016 & 2017 & Ortalama \\
\hline Kontrol & 10,19 & 11,28 & 11,39 & $10,95 \mathrm{C}$ \\
\hline Sökme & 12,22 & 13,15 & 14,08 & $13,15 \mathrm{~B}$ \\
\hline Biçme & 13,64 & 14,77 & 15,72 & $14,71 \mathrm{~A}$ \\
\hline Herbisit & 13,78 & 14,79 & 15,06 & $14,54 \mathrm{~A}$ \\
\hline Gübreleme & 12,78 & 13,92 & 14,12 & $13,61 \mathrm{~B}$ \\
\hline Ortalama & $12,52 \mathrm{~B}$ & $13,58 \mathrm{~A}$ & $14,07 \mathrm{~A}$ & \\
\hline \multicolumn{5}{|c|}{ Tohumlama } \\
\hline Tohumlanmayan & 12,24 & 13,27 & 13,77 & $13,09 \mathrm{~B}$ \\
\hline Tohumlanan & 12,80 & 13,90 & 14,38 & $13,69 \mathrm{~A}$ \\
\hline
\end{tabular}

Bitkilerde mineral elementlerin büyük bir kısmı fizyolojik faaliyetlerinin yoğun olarak gerçekleştiği protoplazmada, çok az bir kısmı ise hücre çeperlerinde bulunmaktadır (Spears, 1994). Olgunlaşmanın ilerlemesinde bağlı olarak çeper bileşiklerinde artış ve protoplazma içeriğinde ise azalma olmaktadır. Bunun sonucunda ise genelde bitki bünyesindeki organik madde oranı artmakta ve mineral madde oranı azalmaktadır (Alatürk, 2012; Gökkuş ve ark. 2012). Dolayısıyla biçilen parsellerdeki bitkiler diğer parsellerdekilere nazaran daha genç kalmış ve mineral element içerikleri daha fazla olmuştur.

Yapılan birçok araştırmada (Koç, 1991; Özaslan, 1996) da belirlendiği gibi, herbisit atılan parsellerin otunda ham kül oranı yükselmektedir. Herbisit ile yem değeri düşük bitkilerle yabancı otların oranlarında azalmalar olurken, baklagil ve buğdaygillerin oranları artmıştır. Ayrıca herbisit uygulaması ile meradaki hıdırellez kamçısı oranı azalmış ve bitki örtüsünde daha kaliteli otsu türler gelişim göstererek topraktan daha fazla mineral almış olabilir. Nitekim mera alanlarında otlayan hayvanlarda vitamin ve mineral element eksikleri pek görülmemektedir (Seydoşoğlu ve Kökten, 2018).

Tohumlama sonucunda otun ham kül içeriğindeki artışın temel nedeni, tohum yatağı hazırlanması sonucunda toprağın havalanması ve havalanan topraklarda bitki kök sisteminin daha aktif olup topraktan daha çok inorganik madde kaldırmaları olabilir (Mut, 2009). Ayrıca havalanan topraklarda artan mikroorganizma faaliyetlerine bağlı olarak toprak organik maddesinin parçalanması ve buna bağlı olarak da toprakta azot ve diğer besin elementlerinin elverişliliği artmaktadır (Weight ve White, 1974).

\section{Sonuç}

Hıdırellez kamçısı ile mücadele amacıyla farklı ıslah yöntemlerinin uygulandığı bu çalışmada hem bitkinin vejetasyondaki gelişme durumu hem de meranın ot verimi ve kalitesi incelenmiştir. Yapılan çalışmanın sonucunda uygulanan sslah yöntemleri meranın ot verimini ortalama $\% 15$ (gübreleme ile \%23) oranında artırmıştır. Sökme, biçme ve tohumlama parsellerinde baklagil ve buğdaygiller, kontrol parselinde ise diğer familyalar artış göstermiştir. Hıdırellez kamçısı üçüncü yılın sonunda gübrelenen ve tohumlanmayan parsellerde artarken, sökme, biçme, herbisit ve tohumlanan alanlarda azalmıştır. Ham protein ve ham kül içerikleri genel olarak kontrol parseline göre diğer uygulamalarda artmış, fakat en belirgin artış biçilen ve tohumlanan alanlarda gerçekleşmiştir. Yürütülen bu araştırmanın neticesinde hıdırellez kamçısının yoğun olduğu benzer meralarda hem bitki ile mücadele hem de meranın ot verimi ve kalitesi artırmak veya korumak amaciyla planlanacak olan çalışmalarda en uygun ıslah yöntemlerinin sökme ve/veya yırtma ile birlikte biçme yapılması gerektiği sonucuna varılmıştır.

Not: Bu çalışma Firat ALATÜRK’ün doktora tezinden üretilmiştir.

\section{Kaynaklar}

Ahuja, L.D., 1972. Range management in arid regions. Bulletin of the Indian National Science Academy, 44: 95102.

Alatürk, F., 2012. Gübrelemenin Çanakkale ili meralarında verim ve otun kimyasal bileşimine etkileri. Yüksek Lisans Tezi. Çanakkale Onsekiz Mart Üni. Fen Bilimleri Enst. Tarla Bitkileri ABD, Türkiye. 
Altın, M., Gökkuş, A., 1988. Erzurum sulu koşullarında bazı yem bitkileri ile bunların karışımlarının değişik ekim şekillerindeki kuru ot verimleri üzerinde bir araştırma. Doğa Tarım ve Orm. Derg., 12(1): 24-36.

Andrae, J., 2003. What is forage quality? http://commodities.caes.uga.edu/ fieldcrops/forages/GA_Cat_Arc/2003/Nov03.pdf.

AOAC, 1990. Official method of analysis (15th Edition). Association of Official Analytical 12 Chemists, Washington, DC., USA, pp. 66-88.

Avağ, A., Koç, A., Kendir, H., 2012. Ulusal mera kullanım ve yönetim projesi sonuç raporu. TÜBİTAK, Proje No: $106 \mathrm{G} 017,483 \mathrm{~s}$

Bakoğlu, A., Gökkuş, A., Koç, A., 1999. Dominant mera bitkilerinin biomas ve kimyasal kompozisyonlarının büyüme dönemindeki değişimi. 2. Kimyasal kompozisyondaki değişimler. Türk tarım ve Orm. Derg, 23(Ek sayı: 2): 495- 508.

Balabanl, C., Albayrak, S., Yüksel, O., 2010. Effects of nitrogen, phosphorus and potassium fertilization on the quality and yield of native rangeland. Turkish J. Field Crops, 15(2): 164-168.

Bilgir, S., 1961. Asphodelus microcarpus Salzmet VIV. (çiriş otu)'na karşı dowpon ilacı ile mücadele denemeleri. Bitki Koruma Bülteni, 2(9): 3-16.

Dahlgren, R.M.T., Clifford, H., Yeo, P.F., 1985. The families of the monocotyledons. Springer Verlag, Berlin.

Diaz Lifante, Z., 1996. Reproductive biology of Asphodelus aestivus (Asphodelaceae). Plant Syst. Evol, 200: $177-191$.

Eltez, S., 1995. İzmir ilinde çiriş otu (Asphodelus microcarpus Viv.) üzerinde yaşayan Capsodes infuscatus (Brul.) (Heteroptera: Miridae)'un morfolojisi, biyolojisi ve zarar şekilleri üzerinde araştırmalar. Doktora Tezi. Ege Üniversitesi, Türkiye.

EUNIS, 2010. EUNIS Biodiversity database. Available at: http://eunis.eea.europa.eu/index.jsp.

Evans, J.R., 1989. Photosynthesis and nitrogen relationships in leaves of C3 plants. Oecologia, 78(1): 9-19.

Goetz, H., 1975. Effect of site and fertilization on protein content of native grasses. J. Range Manage, 28(5): 380-385.

Gökkuş, A., 1984. Değişik ıslah yöntemleri uygulanan Erzurum tabii meralarının kuru ot ve ham protein verimleri ile botanik kompozisyonları üzerinde araştırmalar. Doktora Tezi, Atatürk Üni. Ziraat Fak. Tarla Bitkileri Bölümü, Erzurum.

Gökkuş, A., Koç, A., 1995. Erzurum çayırlarında gübre ve herbisit uygulamalarının kuru ot verimi, botanik kompozisyon ve faydalı ot oranlarına etkileri. Türk Tarım ve Orm. Derg, 19: 23-29.

Gökkuş, A., Koç, A., Çomaklı, B., 1995. Çayır-mera uygulama kılavuzu. Atatürk Üni. Ziraat Fak. Yay. No: 142.

Gökkuş, A., Parlak, A.Ö., Baytekin, H., Hakyemez, B.H., 2012. Akdeniz kuşağı çalılı meralarında otsu türlerin mineral içeriklerinin değişimi. Tekirdağ Ziraat Fak. Derg, 10(1): 1-10.

Griffith, L.W., Schuman, G.E., Rauzı, F., Baumgartner, R.E., 1985. Mechanical renovation of shortgrass prairie for increased herbage production. J. Range Manage, 38(1): 7-10.

Gulmon, S.L., Chu, C.C., 1981. The effects of light and nitrogen on photosynthesis, leaf characteristics, and dry matter allocation in the chaparral shrub, Diplacus aurantiacus. Oecologia, 49(2): 207-212.

Heady, F.H., Child, R.D., 1994. Rangeland ecology and management. Westview Press, Inc., Colorado, 519 p.

Koç, A., 1991. Güzelyurt Köyü (Erzurum) meralarında otlatmaya başlama ve son verme zamanlarının belirlenmesi ile topraküstü bioması ve otun kimyasal kompozisyonunun yıl içerisindeki değişimi üzerine bir araştırma. Yüksek Lisans Tezi, Atatürk Üni. Fen Bilimleri Enst. Tarla Bitkileri ABD, Türkiye.

Koç, A., Gökkuş, A., Bakoğlu, A., Özaslan, A., 2000. Erzurum'da Palandöken dağı meralarının farklı lokasyonlarından alınan ot örneklerinde bazı kimyasal özelliklerin otlatma sezonundaki değişimi. Int. Animal Nutrition Cong., 4-6 September, 2000, Isparta, Turkey, 471-478.

Mengel, K., 1984. Bitkinin beslenmesi ve metabolizması. Çevirenler: H. Özbek, Z. Kaya, M. Tamcı, Çukurova Üni. Ziraat Fak. Yay: 162. Ders Kitab1: 12, 590s.

Mullen, G.J., Jeley, R.M., Mc Alieese, D.M., 1974. Effect of animal treading on soil properties and pasture production. Irish. J. Agri. Research, 13(2): 171-180.

Mut, H., 2009. Sürülüp terkedilen bir merada farklı 1slah yöntemlerinin etkinliklerinin belirlenmesi. Doktora Tezi, Ondokuz Mayıs Üni. Fen Bilimleri Enst. Tarla Bitkileri ABD, Türkiye.

Önder, F., Karsavuran, Y., 1986. İzmir çevresinde çiriş otu (Asphodelus microcarpus Viv.)'na karş1 uygulanacak biyolojik savaşta Capsodes infuscatus (Brul.) (Heteroptera: Miridae)'un etkinliği üzerinde gözlemler. Türkiye 1. Biyolojik Mücadele Kongresi, 12-14 Şubat, 1986, Adana, 270-279.

Özaslan, A., 1996. Erzurum ekolojik şartlarında taban mera bitki örtülerinin ıslahı üzerine yırtma, gübreleme ve herbisit uygulamalarının etkileri. Yüksek Lisans Tezi, Atatürk Üni. Fen Bilimleri Enst. Tarla Bitkileri ABD, Türkiye.

Polunin, O., Huxley, A., 1987. Flowers of the Mediterranean. Hogarth Press, London.

Rimmer, D.L., 1997. Effects of increasing compaction on grass growth in colliery spoil. J. The Sports Turf Research Institute, 55,153-162. 
Sawidis, T., Kalyva, S., Delivopoulos, S., 2005. The root-tuber anatomy of Asphodelus aestivus. Elsevier- Flora, 200: 332-338.

Seydoşoğlu, S., Kökten, K., 2018. Batman İli Beşiri ilçesi mera vejetasyonlarının bazı özellikleri. Ege Üniv. Ziraat Fak. Derg, 55(4): 491-497.

Serin, Y., 1982. Erzurum sulu ve kıraç şartlarında yetiştirilen kılçıksız broma uygulanan değişsik sıra aralığı ve gübrelerin ot ve tohum verimleriyle bazı verim unsurlarına etkileri üzerinde bir araştırma. Doçentlik Tezi. Atatürk Üniversitesi, Türkiye.

Spears, J.W., 1994. Minerals in forages. In: Fahey G.C., Ed., Forage Quality, Evaluation, and Utilization, ASA, CSSA, SSA, Wisconsin, 281-317.

Stafford, L.T., Odonovan, S.F., Raftery, T.F., 1980. The "Stilching-in" technique for renovation. Irish J. Afric. Res, 17: 283-294.

Sürmen, M., 2010. Orta Karadeniz Bölgesinde Kofa (Juncus effusus L.) istilasına uğrayan meralar için uygun ıslah yöntemlerinin belirlenmesi. Doktora Tezi. Atatürk Üniversitesi, Türkiye.

Traxler, M.J., Fox, D.G., Van Soest, P.J., Pell, A.N., Lascano, C.E., Lanna, D.P.D., Moore, J.E., Lana, R.P., Ve'lez, M., Flores, A., 1998. Predicting forage indigestible NDF from lignin concentration. J. Anim. Sci, 76: 1469-1480.

Tükel, T., Hatipoğlu, R., 2001. Çayır-meralarda zehirli bitkiler ve hayvanlar üzerindeki etkileri. Tarım ve Köy, 139: 40-43.

Undersander, D.J., Bertman, M.G., Clark, J.R., Crooks, A.E., Rankin, M.C., Silveria, K.G., Wood, T.M., 2005. Forage variety update for Wisconsin. 2005 Trial Results. Univ. of Extention Publ. A1525, Wisconsin, $28 \mathrm{p}$.

Uygun, N., Koç, N.K., Uygur, N., Karaca, İ., Uygur, S., Küsek, N., 1994. Doğu Akdeniz Bölgesi çayır meralarındaki yabancı ot türleri ve doğal düşmanları üzerine araştırmalar. Türkiye 3. Biyolojik Mücadele Kongresi, 25-28 Ocak, 1994, Bornova, İzmir: 321-330.

Weight J.R., White, L.M., 1974. Interseeding and pitting on a site in Eastern Montana. J. Range Manage, 27(3): 206-210.

Weryszko-Chemielewska, E., Sawidis, T., Piotrowska, K., 2006. Anatomy and ultrastructure of floral nectarines of Asphodelus aestivus Brot. (Asphodelaceae). Acta Agrobotanica, 59(2): 29-42.

Whitehead, D.C., 2000. Nutrient elements in grassland soil-plant-animal relationships. CABI Publishing, 369p. 